\title{
IMMEDIATE STRENGTH AFTER SUTURE OF A TORN ANTERIOR CRUCIATE LIGAMENT
}

\author{
W. J. P. RADFORD, A. A. AMIS, F. W. HEATLEY \\ From Imperial College, London, England
}

In an animal model we determined the strength of anterior cruciate ligaments (ACL) after section and repair by four different methods and compared it with that of the intact ligament. The standard suturing technique of multiple loops through the ligament stumps was used. Stronger suture material did not give a stronger repair. Wrapping a fine polyester mesh around the ligament or placing it between the bundles before suture increased the strength of the repair. This modification, allied to protective rehabilitation, may reduce the failure rate of acute $A C L$ repairs.

J Bone Joint Surg [Br] 1994; 76-B:480-4.

Received 29 July 1993; Accepted 31 August 1993

Rupture of the anterior cruciate ligament (ACL) with no repair results in absorption and shortening of the ligament (O'Donoghue et al 1966), but Whiteside and Sweeney (1980) found that the stumps remained viable, gaining their nutrition from the diffusion of synovial fluid. Arnoczky, Rubin and Marshall (1979) showed that in dogs a surgically created lesion resulted in a vascular response throughout the ligament, and observations in monkeys suggest that injured anterior cruciate ligaments should be capable of repair (Cabaud, Rodkey and Feagin 1979). Earlier experimental work by O'Donoghue et al (1966) showed that in dogs carefully repaired cruciate ligaments which were then immobilised for six weeks showed good repair by ligamentous tissue. These experiments indicate that ACL healing is affected by the proximity and apposition of the torn ends, by the local

W. J. P. Radford, ChM, FRCS Ed, Clinical Research Fellow

A. A. Amis, PhD, CEng, MIMech E, Senior Lecturer in Mechanical Engineering

Biomechanics Section, Department of Mechanical Engineering, Imperial College of Science, Technology and Medicine, Exhibition Road, London SW7 2BX, UK.

F. W. Heatley, FRCS, Reader in Orthopaedic Surgery

St Thomas' Hospital, Lambeth Palace Road, London SE1 7EH, UK.

Correspondence should be sent to Dr A. A. Amis.

C1994 British Editorial Society of Bone and Joint Surgery 0301-620X/94/3745 \$2.00 blood supply, and by other local environmental factors (Andrish 1984).

The management of the acutely ruptured ACL in patients is controversial. Some authors have advised conservative treatment (Chick and Jackson 1978; McDaniel and Dameron 1980; Balkfors 1982; Giove et al 1983; Jokl et al 1984) while others favour surgical repair (Palmer 1938; O'Donoghue 1950; Liljedahl, Lindvall and Wetterfors 1965; Aho, Lehto and Kujala 1966; Eriksson 1976; Cabaud, Feagin and Rodkey 1980; Fetto and Marshall 1980; Gerber and Matter 1983). It has been reported that acutely repaired ligaments do well for up to two years, but that knee function decreases significantly by five years (Feagin and Curl 1976; Odensten, Lysholm and Gillquist 1984). Other studies, however, have found no deterioration in results at second follow-up (Marshall et al 1979), even after an average of seven years (Gollehon, Torzilli and Warren 1987).

The effect of repair on other knee structures is also important. Müller (1983) found that good or perfect stability could be restored in many cases by the suture of fresh isolated cruciate ligament ruptures, and others have reported that few meniscectomies were needed after acute ACL repair (Marshall, Warren and Wickiewicz 1982; Warren 1983; Gollehon, Warren and Wickiewicz 1985). This is in contrast with the high rates of meniscal degeneration noted in patients with chronic insufficiency of the ACL (Galway, Beaupré and MacIntosh 1972; Alm 1974). This tends to support O'Donoghue's contention that a repaired $A C L$ which maintains tensile strength will also tend to maintain joint stability ( $O$ 'Donoghue et al 1971).

Nevertheless, primary suture alone is rarely undertaken, perhaps because of an unacceptable proportion of failures. Current practice is therefore to manage conservatively, to use an autogenous graft such as the middle third of the patellar tendon, or to reinforce a primary repair with an autogenous graft or an artificial augmentation device.

It is not clear why simple repair fails to give consistent results. There is evidence that the ligament can heal, and it may therefore be a matter of suture technique. Hand surgeons have developed improved techniques for the repair of flexor tendons, but knee surgeons have not yet reported equivalent methods for ligaments. We have assessed the immediate strength after four methods of 


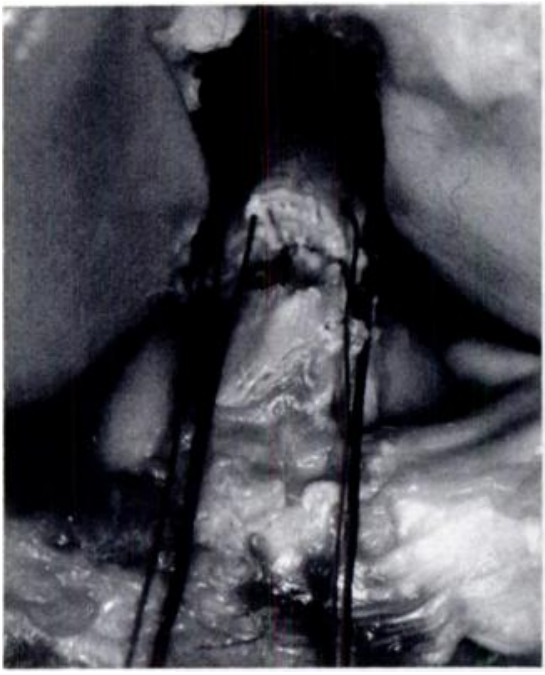

Fig. 1a

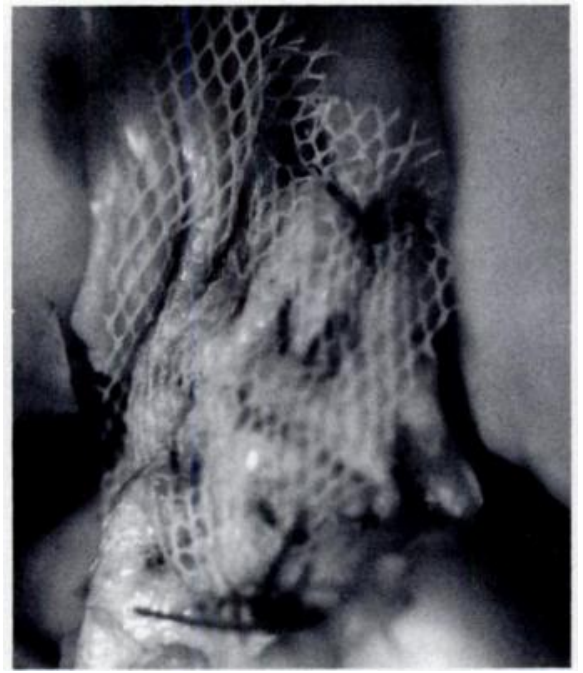

Fig. $1 \mathrm{~b}$

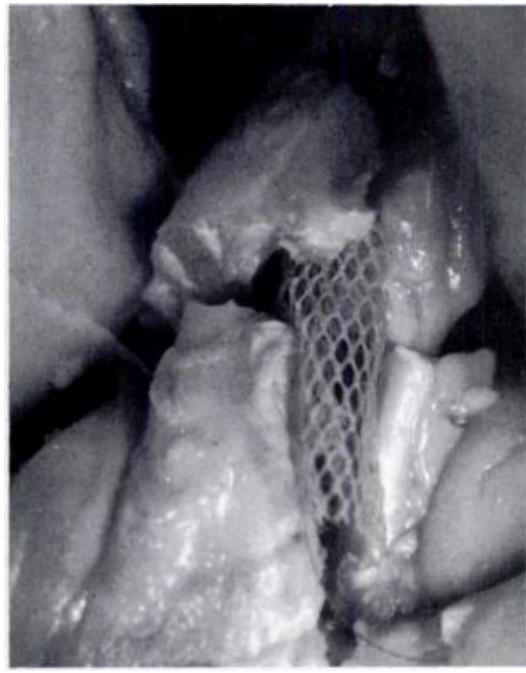

Fig. 1c

Figure 1a - Multiple loops placed in the proximal stump for repair of a bovine ACL. Figure 1b - Repair using a polyester mesh 'corset' wrapped round the ligament before suturing. Figure $1 \mathrm{c}$ - Repair using a polyester mesh 'splint' inserted lengthwise between the ligament bundles before suturing.

ligament repair, including the use of multiple loops and of polyester mesh.

\section{MATERIALS AND METHODS}

We used 16 bovine stifles (knees) which were obtained fresh, sealed in polyethylene bags and stored at $-18^{\circ} \mathrm{C}$. Before testing, the joints were thawed to room temperature in warm water still inside the bags and then stripped of muscle and soft tissues. The patella, patellar ligament and fat pad were excised, leaving the rest of the capsule intact. The integrity of the interior of the joint and of the anterior (cranial) cruciate ligament (ACL) were confirmed and the circumference of the mid-part of the ACL was measured using a piece of fine thread. The ACL was then divided transversely at this level with a scalpel and, to facilitate apposition of the cut ends, the posterior (caudal) cruciate ligament (PCL) was excised.

The joints were studied in four groups of four. The suture technique was that of Gollehon et al (1985), using four sutures placed as multiple loops through each end of the divided ligament (Fig. 1a). The ends of the sutures passed through the proximal part of the ligament were brought out distally through two $4 \mathrm{~mm}$ tibial drill holes placed to enter the joint at the attachment sites of the two bundles of the ACL, and tied over the front of the tibia. The lateral ends of the loops placed through the distal part of the ligament were passed through a $4 \mathrm{~mm}$ drill hole in the lateral femoral condyle, while the medial ends were passed 'over-the-top' of the femoral condyle, before tying the bundles together on the bone surface.

In the first two groups, we compared multiple loops of ' $2 / 0$ ' braided polyester (Ethibond; Ethicon UK Ltd, Edinburgh, UK) with the stronger size ' 0 ' sutures of the same material. The third and fourth groups had ' 0 ' sutures augmented with a fine polyester mesh (Mersilene; Ethicon
UK Ltd). Group 3 had a mesh 'corset' on the ligament surface (Fig. 1b) and in group 4 the mesh was used as a splint placed between the bundles of the ACL (Fig. 1c). The corset was wrapped around the ligament and attached to its surface by interrupted $2 / 0$ braided polyester sutures at 2 to $3 \mathrm{~mm}$ intervals. The splint was sutured in place at each end. In both groups, the multiple loops were then passed through both the mesh and the ACL. In summary:

1) multiple loops of $2 / 0$ Ethibond;

2) multiple loops of ' 0 ' Ethibond;

3) multiple loops of ' 0 ' Ethibond plus a mesh corset; and

4) multiple loops of ' 0 ' Ethibond plus a mesh splint.

After repair, specimens were tested in an Instron 1122 materials tensile testing machine. The femur was clamped horizontally by its trochlea to the crosshead and the tibia was clamped vertically by its shaft to the base. After transecting all soft tissues linking the femur to the tibia except the repaired ACL, the specimens were pulled apart at $100 \mathrm{~mm} / \mathrm{min}$ while a plot was made of force against the upward movement of the crosshead.

The point at which a $2 \mathrm{~mm}$ gap first appeared between the cut ends of the ACL was marked on the graph plotter during the test. This size of gap was chosen as indicative of technical failure by disruption of the repair and elongation of the ligament. The onset of failure was clearly seen because, at $90^{\circ}$ flexion, the anterior fibres were the first to tighten.

\section{RESULTS}

The repairs are illustrated in Figure 1, and the mean strengths and standard deviations for the different techniques are given in Table $I$. We used the unpaired Student's $\boldsymbol{t}$-test with $\mathrm{p}<0.05$ for significance to analyse the differences between the four groups.

Circumference. The circumferences of the ACL after 
Table I. Results for circumference, force and extension at a $2 \mathrm{~mm}$ gap and force and extension for ultimate strength of the four types of $A C L$ repair as mean \pm SD. For each group, $\mathrm{n}=4$

\begin{tabular}{|c|c|c|c|c|c|}
\hline & \multirow[b]{2}{*}{$\begin{array}{l}\text { Circumference } \\
(\mathbf{m m})\end{array}$} & \multicolumn{2}{|l|}{$2 \mathrm{~mm}$ gap } & \multicolumn{2}{|c|}{ Ultimate strength } \\
\hline & & $\begin{array}{l}\text { Force } \\
\text { (N) }\end{array}$ & $\begin{array}{l}\text { Extension } \\
(\mathbf{m m})\end{array}$ & $\begin{array}{l}\text { Force } \\
\text { (N) }\end{array}$ & $\begin{array}{l}\text { Extension } \\
(\mathbf{m m})\end{array}$ \\
\hline Multiple loops $(2 / 0)$ & $41.8 \pm 3.9$ & $86.3 \pm 30.4$ & $11.3 \pm 1.0$ & $193.3 \pm 15.9$ & $25.3 \pm 6.8$ \\
\hline Multiple loops (0) & $43.0 \pm 4.3$ & $91.8 \pm 9.4$ & $12.0 \pm 1.6$ & $196.5 \pm 48.2$ & $24.5 \pm 6.2$ \\
\hline $\begin{array}{l}\text { Multiple loops }(0) \\
+ \text { mesh corset }\end{array}$ & $43.0 \pm 3.4$ & $161.3 \pm 49.6$ & $12.9 \pm 2.2$ & $294.0 \pm 30.1$ & $26.0 \pm 2.8$ \\
\hline $\begin{array}{l}\text { Multiple loops (0) } \\
+ \text { mesh splint }\end{array}$ & $40.8 \pm 1.7$ & $176.5 \pm 26.2$ & $10.5 \pm 1.9$ & $320.8 \pm 51.1$ & $20.3 \pm 5.9$ \\
\hline
\end{tabular}

repair in the four groups were not significantly different $(p=0.28)$; the addition of the mesh did not produce an unacceptably bulky repair.

Gap formation. The force at which a $2 \mathrm{~mm}$ gap appeared was not significantly different $(p=0.74)$ for the $2 / 0$ and 0 multiple loop repairs, being $86.3 \mathrm{~N} \pm 30.4$ and $91.8 \mathrm{~N} \pm$ 9.4 respectively (Table I, Fig. 2). The thicker, stronger 0 suture material did not give a significantly enhanced resistance because the sutures were pulled through the ligament at failure and did not themselves fail.

The addition of mesh to the 0 multiple loops increased the strength of the repair significantly to $161.3 \mathrm{~N}$ \pm 49.6 when it was used as a corset $(p=0.03)$ and to $176.5 \mathrm{~N} \pm 26.2$ when used as a splint $(p=0.001)$. Although the splint was slightly stronger than the corset, the difference was not significant $(p=0.61)$.

Ultimate strength. The mean ultimate strength for the $2 / 0$ multiple loops was $193.3 \mathrm{~N} \pm 15.9$, and for the 0 sutures was $196.5 \mathrm{~N} \pm 48.2(\mathrm{p}=0.90)$. Reinforcement with mesh increased the ultimate strength to $294.0 \mathrm{~N} \pm$ 30.1 when used as a corset $(\mathrm{p}=0.014)$ and $320.8 \mathrm{~N} \pm$ 51.1 when used as a splint $(p=0.012)$. Again there was no significant difference between its use as a corset or as a splint $(\mathrm{p}=0.40)$.

Extension. There was no significant difference between the groups for either the extensions at which a $2 \mathrm{~mm}$ gap occurred $(p=0.15)$ or at ultimate strength $(p=0.13)$ (Table I).

\section{DISCUSSION}

The aim of treatment for a disabling ACL injury is to return the knee as closely as possible to normality. The most common method at present is probably an autogenous tissue reconstruction. There are, however, some doubts about harvesting the graft from the soft tissues around an already damaged joint and such a graft may not mature into a normal ligament (Bosch et al 1989). There is also concern that proprioception may be compromised (Zimny, Schutte and Dabezies 1986). Direct repair of the $\mathrm{ACL}$ is therefore theoretically attractive, but is rarely used because of an unacceptable failure rate. The cause for this is that most repairs are weak and easily disrupted. It seems

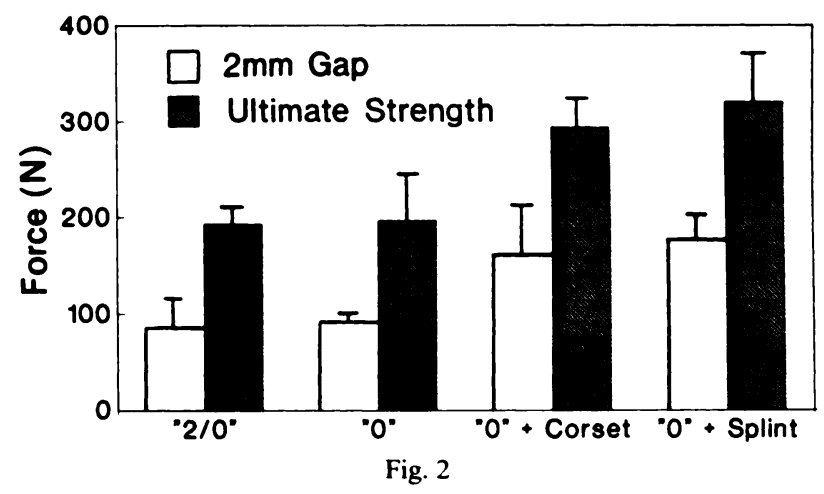

Bar chart showing the mean forces \pm 1 SD at a $2 \mathrm{~mm}$ gap and the mean ultimate strengths for each of the four types of repair.

logical to try to develop a stronger, but still practical method.

In hand surgery, there was a move from primary repair to the routine use of autogenous grafts for finger flexor tendon injuries (Bunnell 1956). However, the development of stronger suturing methods (Kessler and Nissim 1969; Ketchum, Martin and Kappel 1977; Savage 1985; Wade, Wetherell and Amis 1989; Mashadi and Amis 1992) has allowed a move back to primary repairs, allowing earlier active motion, better rehabilitation and improved results (Lister et al 1977).

The ACL presents a similar problem and although there are data for tensile strength at various times after ACL repair (McDaniel and Dameron 1980), we could find no reports on strength immediately after repair. Our initial hypothesis was that the use of the locking loops and criss-crosses developed by hand surgeons would give greater strength to ACL repair. This was not so; it has been shown that it is the transverse passes of suture material which give holding strength and not the other complexities (Mashadi and Amis 1991). We therefore concentrated on trying to improve the strength of a conventional 'multi-loop' repair technique.

The main difficulty in ACL suture is the poor holding power of the ruptured ends. They have been described as 'mop ends' or 'brushes', accurately depicting the separation into multiple fibres or fascicles. For this reason stronger, thicker sutures made no significant difference to 
the strength of the repair. Our repairs used four loops in each stump; their strength could have been improved by increasing the number of loops, but we were looking for a method of providing greater cohesion and holding power for each suture. One approach would have been to use a tissue adhesive, but we felt that this would be impractical in the clinical situation of bunches of wet fibres. We therefore tested the use of a mesh to approximate the fibres and give an improved hold for sutures. We found that adding mesh increased the mean ultimate strength by $50 \%$ when it was used as a corset and by $63 \%$ when used as a splint, with no significant difference between these methods.

We considered that it was better to use an artificial material which remained permanently in a quiescent state, rather than resorbable materials such as polydioxanone (PDS; Ethicon UK Ltd) or polytrimethylene carbonate (Maxon; Davis and Geck Ltd, Gosport, UK). They are known to lose much of their strength by four to six weeks (Bourne et al 1988) which would be too fast for ACL healing. In terms of joint reaction the splint method may be preferable to the corset, since the implanted material is less exposed and therefore less likely to be abraded against bone which might liberate particles that could cause synovitis. It has been shown that polyester fibres do not cause synovitis in the knee when they are embedded in host tissue (Amis et al 1992).

The mean ultimate strength of the bovine ACL is approximately $6500 \mathrm{~N}$ (Moss and Ferguson 1980); our best repair achieved only a mean ultimate strength of
$320 \mathrm{~N}$, or about $5 \%$ of normal. This could probably have been improved by the use of more loops. This was therefore a weak repair, despite the good access to the bovine stifles, surgical transection, no other damage and detensioning by excision of the PCL. These circumstances allowed the cut ends to be neatly opposed and the specimen to be held immobile for suture. The laboratory study was thus optimistic in relation to the clinical reality. It may seem tempting to extend the use of the mesh beyond the ACL and attach it to bone, but this would then become ligament augmentation rather than repair and introduce factors such as stress-shielding and implant fatigue.

The strength of our methods applied in clinical repair is uncertain, but if $50 \%$ of the experimental strength could be attained, some $160 \mathrm{~N}$ breaking strength, then repair using mesh would withstand the forces calculated to act on the ACL during walking (Morrison 1969). After flexor tendon surgery in the hand, a similar situation has been met by devising controlled rehabilitation to prevent disruption of repairs. The development of a similar protective regime for the $\mathrm{ACL}$, together with the increase in strength achieved by suturing through polyester mesh, might reduce the proportion of failures seen after direct repair of an acutely injured ACL.

This study was funded by the Wellcome Trust, which we thank. The Instron machine was provided by the Arthritis and Rheumatism Council for Research.

No benefits in any form have been received or will be received from a commercial party related directly or indirectly to the subject of this article.

\section{REFERENCES}

Aho AJ, Lehto MUK, Kujala UM. Repair of the anterior cruciate ligament: augmentation versus conventional suture of fresh rupture. Acta Orthop Scand 1966; 57:354-7.

Alm A. Old injuries of the liagments of the knee joint. Acta Chir Scand 1974; 140:283-8.

Amis AA, Camburn M, Kempson SA, Radford WJP, Stead AC Anterior cruciate ligament replacement with polyester fibre: a longterm study of tissue reactions and joint stability in sheep. $J$ Bone Joint Surg [Br] 1992; 74-B:605-13.

Andrish JT. Ligamentous injuries of the knee. Prim Care 1984; II:77-8.

Arnoczky SP, Rubin RM, Marshall JL. Microvasculature of the cruciate ligaments and its response to injury: an experimental study in dogs. J Bone Joint Surg [Am] 1979; 61-A:1221-9.

Balkfors B. The course of knee-ligament injuries. Acta Orthop Scand 1982; 53 Suppl 198:7-99.

Bosch U, Decker B, Kasperczyk W, Oestern HJ, Tscherne H. Biological aspects of long-term failure of autografts after cruciate ligament replacement. Arch Orthop Trauma Surg 1989; 108:368-72.

Bourne RB, Bitar H, Andreae PR, et al. In-vivo comparison of four absorbable sutures: vicryl, dexon plus, maxon \& PDS. Can J Surg $1988 ; 31: 43-5$.

Bunnell S. Surgery of the hand. Third ed. London: Pitman Medical Publishing Co Ltd/Philadelphia: JB Lippincott Co, 1956.

Cabaud HE, Feagin JA, Rodkey WG. Acute anterior cruciate ligament injury and augmented repair. Am J Sports Med 1980; 8:395-401.

Cabaud HE, Rodkey WG, Feagin JA. Experimental studies of acute anterior cruciate ligament injury and repair. Am J Sports Med 1979 7:18-22.
Chick RR, Jackson DW. Tears of the anterior cruciate ligament in young athletes. J Bone Joint Surg [Am] 1978; 60-A:970-3.

Eriksson E. Sports injuries of the knee ligaments: their diagnosis, treatment, rehabilitation and prevention. Med Sci Sports 1976; 8:133-44.

Feagin JA Jr, Curl WW. Isolated tear of the anterior cruciate ligament: five-year follow-up study. Am J Sports Med 1976; 4:95-100.

Fetto JF, Marshall JL. The natural history and diagnosis of anterior cruciate ligament insufficiency. Clin Orthop 1980; 147:29-38.

Galway RD, Beaupré A, MacIntosh DL. Pivot shift: a clinical sign of symptomatic anterior cruciate ligament insufficiency. $J$ Bone Joint Surg [Br] 1972; 54-B:763-4.

Gerber C, Matter P. Biomechanical analysis of the knee after rupture of the anterior cruciate ligament and its primary repair: an instant-centre analysis of function. J Bone Joint Surg [Br] 1983; 65-B:391-9.

Giove TP, Miller SJ III, Kent BE, Sanford TL, Garrick JG. Nonoperative treatment of the torn anterior cruciate ligament. J Bone Joint Surg [Am] 1983; 65-A:184-92.

Gollehon DL, Warren RF, Wickiewicz TL. Acute repairs of the anterior cruciate ligament: past and present. Orthop Clin North Am 1985, 16:111-25.

Gollehon DL, Torzilli PA, Warren RF. The role of the posterolateral and cruciate ligaments in the stability of the human knee. $J$ Bone Joint Surg [Am] 1987; 69-A:233-42.

JokJ P, Kaplan N, Stovell P, Keggi K. Non-operative treatment of severe injuries to the medial and anterior cruciate ligaments of the knee. $J$ Bone Joint Surg [Am] 1984; 66-A:741-4. 
Kessler I, Nissim F. Primary repair without immobilization of flexor tendon division within the digital sheath: an experimental and clinical study. Acta Orthop Scand 1969; 40:587-601.

Ketchum LD, Martin NL, Kappel DA. Experimental evaluation of factors affecting the strength of tendon repairs. Plast Reconstr Surg 1977; 59:708-19.

Liljedahl S-O, Lindvall N, Wetterfors J. Early diagnosis and treatment of acute ruptures of the anterior cruciate ligament: a clinical and arthrographic study of forty-eight cases. J Bone Joint Surg [Am] 1965; 47-A:1503-13.

Lister GD, Kleinert HE, Kutz JE, Atasoy E. Primary flexor tendon repair followed by immediate controlled mobilization. J Hand Surg 1977; 2:441-51.

Marshall JL, Warren RF, Wickiewicz TL, Reider B. The anterior cruciate ligament: a technique of repair and reconstruction. Clin Orthop 1979; 143:97-106.

Marshall JL, Warren RF, Wickjewicz TL. Primary surgical treatment of anterior cruciate ligament lesions. Am J Sports Med 1982; 10:103-7.

Mashadi ZB, Amis AA. The effect of locking loops on the strength of tendon repair. J Hand Surg [Br] 1991; 16:35-9.

Mashadi ZB, Amis AA. Strength of the suture in the epitenon and within the tendon fibres: development of stronger peripheral suture technique. $J$ Hand Surg [Br] 1992; 17:172-5.

McDaniel WJ Jr, Dameron TB Jr. Untreated ruptures of the anterior cruciate ligament: a follow-up study. J Bone Joint Surg [Am] 1980; 62-A:696-705.

Morrison JB. Function of the knee joint in various activities. Biomed Engin 1969; 4:573-80.
Moss EW, Ferguson TH. Tensile strength of the cranial cruciate ligament in cattle. Am J Vet Res 1980; 41:1408-11.

Müller W. The knee: form, function and ligament reconstruction. New York, etc: Springer-Verlag, 1983.

O'Donoghue DH. Surgical treatment of fresh injuries to the major ligaments of the knee. J Bone Joint Surg [Am].1950; 32-A:721-38.

O'Donoghue DH, Rockwood CA, Frank GR, Jack SC, Kenyon R. Repair of the anterior cruciate ligament in dogs. $J$ Bone Joint Surg [Am] 1966; 48-A:503-19.

O'Donoghue DH, Frank GR, Jeter GL, et al. Repair and reconstruction of the anterior cruciate ligament in dogs: factors influencing long-term results. J Bone Joint Surg [Am] 1971; 53-A:710-8.

Odensten M, Lysholm J, Gillquist J. Suture of fresh ruptures of the anterior cruciate ligament: a 5-year follow-up. Acta Orthop Scand $1984 ; 55: 270-2$.

Palmer I. On the injuries to ligaments of knee joint: clinical study. Acta Chir Scand 1938:81 Suppl 53:3-282.

Savage $\mathbf{R}$. In vitro studies of a new method of flexor tendon repair. $J$ Hand Surg [Br] 1985; 10-B:135-41.

Wade PJF, Wetherell RG, Amis AA. Flexor tendon repair: significant gain in strength from the Halsted peripheral suture technique. $J$ Hand Surg [Br] 1989; 14:232-5.

Warren RF. Primary repair of the anterior cruciate ligament. Clin Orthop 1983; 172:65-70.

Whiteside LA, Sweeney RE. Nutrient pathways of the cruciate ligaments: an experimental study using the hydrogen wash-out technique. $J$ Bone Joint Surg [Am] 1980; 62-A:1176-80.

Zimny ML, Schutte M, Dabezies E. Mechanoreceptors in the human anterior cruciate ligament. Anat Rec 1986; 214:204-9. 